\title{
血栓症を伴う頸動脈痛(Carotidynia)：血管炎症と血栓に関わる考察
}

松原宏紀 ${ }^{1}$, 竹下享典 ${ }^{1,2 *}$

\section{Carotidynia with carotid arterial thrombosis: missing link between inflammation and thrombosis}

Hiroki MATSUBARA, ${ }^{1}$ Kyosuke TAKESHITA ${ }^{1,2 *}$

Key words: carotidynia, carotid arterial thrombosis, carotid echography

\section{1.はじめに}

血栓による頸動脈狭窄は，動脈硬化に起因する高 度狭窄，破綻したプラークの潰瘍病変，解離性大動 脈瘤にみられ，脳塞栓，一過性脳虚血発作の診察の 際，頸動脈超音波検査などの画像検査で認められ る.このように頸動脈血栓の多くは動脈硬化の進行 に伴うことが知られているが，それ以外が原因とな ることは稀である。今回, 頸動脈痛 (carotidynia)が原 因と考えられる血栓性内頸動脈狭窄に対し, 頸動脈 ステント留置術を行った稀少な症例を経験した1). Carotidynia は本邦での報告は少なく，これが原因と なった血栓症の報告は世界的にも例をみない。診断 に難渋し, 各種画像診断, 病理組織診断での複合的 な評価を必要とした貴重な経験であったため以下報 告する.

\section{Carotidynia とは}

Carotidynia は片側性の頸動脈の部位に一致する圧 痛という症状を主体とした原因不明の症候群であ る。国際頭痛分類第 1 版ではその定義は「持続期間 が 2 週間未満の頸部痛で, 頸動脈分岐部触診時の圧 痛を伴うもの」(表 1)であり，第 2 版では，MRIに よる症候性動脈周囲組織における MRI 異常所見 (T1

${ }^{1}$ 名古屋大学医学部附属病院検査部

2 名古屋大学大学院医学系研究科病態内科学講座循環器内 科学

*責任者連絡先：kyousuke@med.nagoya-u.ac.jp
強調画像にて中等度信号として描出され，ガドリニ ウム注入後に潜在性リングとして増強される)を伴 うものがある，という項目が追加されている21. 実 際多くの症例報告によると，検査所見は，炎症反応 の上昇を認めず，生検所見においては非特異的な炎 症所見を示すのみで所見にそしい ${ }^{3)}$ 。これに対して 画像診断の所見は，頸動脈分岐部の血管周囲部の炎 症を示唆する特異的なもので, 頸動脈血管壁の肥

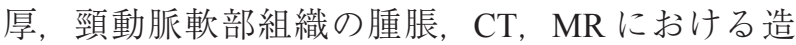
影効果を有する軟部組織陰影, FDG-PET での病変 部高集積が症例報告で示されている゙3. 鑑別には動 脈炎, 動脈瘤, 甲状腺疾患, 頸部リンパ節疾患, 頸 動脈小体腫瘍などの頸部腫瘍などの疾患が除外され る必要がある。多くの臨床経過は, 自然軽快するも の，NSAID，ステロイドを一過的に使用すること で軽快するもの，といずれも良好である。

\section{3. 自験例}

【症例】 60 歳, 男性

【既往歴】高血圧

【現病歴】右頸部痛と一過性黒内障を主訴にがん専門 病院を紹介受診したが，MRI 上頸動脈に異常所見 があり，当院へ紹介となった。初診時，右頸部痛以 外, 四肢麻瘏, 痺れなどの症状はなかった，視診上, 発赤，腫脹などの異常所見はみられず，神経学的異 常所見は認められなかった。手術，外傷の既往もな かった，頸動脈超音波検査で，軽－中等度動脈硬化 のみならず，血栓性高度狭窄を合併していることか 
表 1 国際頭痛分類第 1 版
A. At least one of the following overlying the carotid artery
1. Tenderness
2. Swelling
3. Increased pulsations
B. Appropriate investigations not revealing structural abnormality
C. Pain over the affected side of the neck; may project to the ipsilateral side of the head
D. A self-limiting syndrome of less than 2 weeks' duration

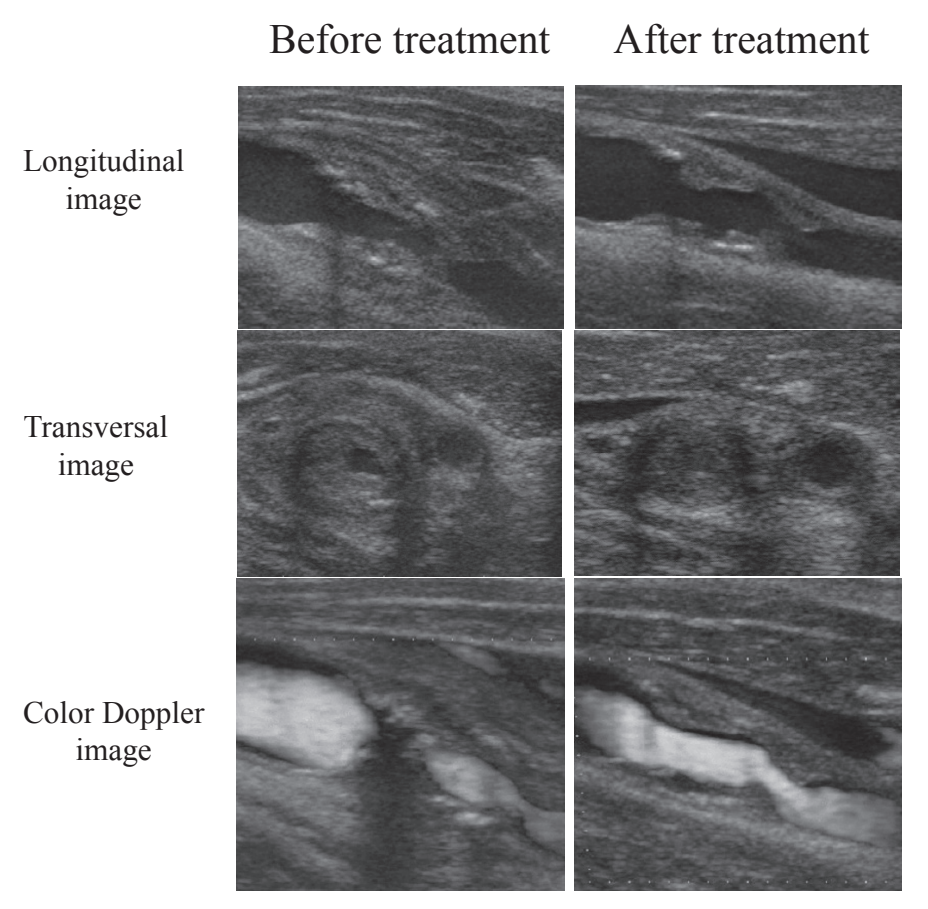

図 1 Carotid artery echographic images.

ら緊急入院となった。 入院後の胸部 $\mathrm{CT}$ では上行大 動脈, 大動脈弁, 冠動脈に僅かな石灰化を認めたが, 他に腫瘍, 炎症, 大動脈解離などの異常所見は認め なかった。

入院時血液検査所見では, CRP は $0.6 \mathrm{mg} / \mathrm{dL}$ と軽 度上昇し, 赤血球沈降速度も 1 時間值 $33 \mathrm{~mm}$ と高 值だったが, その他の生化学検査, 血液検査, 凝固 検査, 各種腫瘍マーカーは基準值内であり, 血液培 養も陰性であった。

\section{【治療前の頸動脈超音波検査】(図 1)}

ステロイド治療前は, 右頸動脈球部から内頸動脈 近位部の血管壁および周囲軟部組織に, 浮腫による
腫脹を認めた，そして内頸動脈には，血栓による血 流速の著明な上昇を伴う（流速 $2.99 \mathrm{~m} / \mathrm{s}$; 流速が $2 \mathrm{~m}$ を超える所見は有意な狭窄である) 高度狭窄(面積狭 窄率 96.2\%) を認めた。

\section{【頸部の MRI, CT, FDG/PET】}

MRI では, T2 強調画像で右内頸動脈分岐部付近 に血管を取り囲むように軟部組織の浮腫像を認め, $\mathrm{T} 1$ 強調画像で内頸動脈内腔に高信号を示す血栓に よる狭窄像を認めた。造影 $\mathrm{T} 1$ 強調画像では, 内頸 動脈周囲組織は淡く造影されており(図 $2 \mathbf{A}$ 矢印), 国際頭痛分類第 2 版に記載されたガドリニウムによ る増強所見に相当すると考えられる。CTでも浮腫 

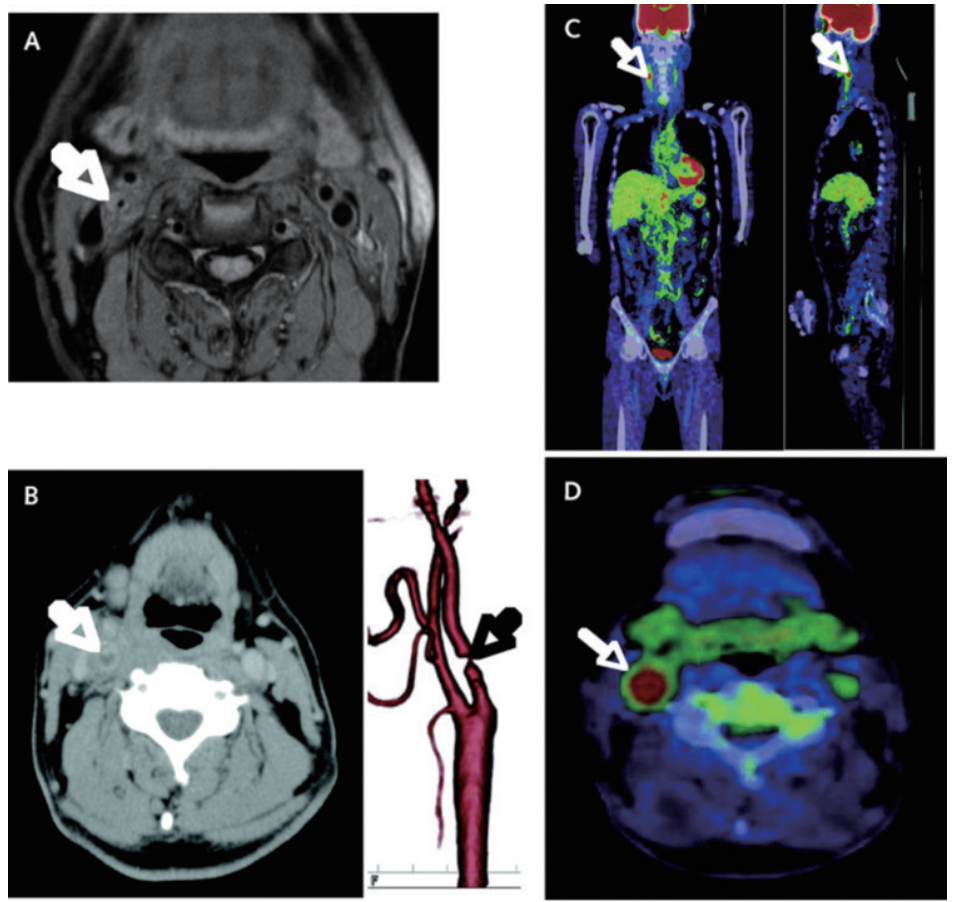

図 2 MRI, CT, and PET-CT images. ${ }^{1)}$ A. Cranial axial magnetic resonance image showing wall thickening in the proximal right internal carotid artery with stenosis (arrow) surrounded by edematous perivascular tissue. B, left. Cranial axial computed tomographic image showing the internal carotid artery with thrombotic stenosis (arrow). B, right. Three-dimensional computed tomographic image showing severe stenosis in the internal carotid artery (arrow). C and D. ${ }^{18} \mathrm{~F}$-fluorodeoxyglucose positron emission tomographic-computed tomographic images of the whole body $(C)$ and cranium $(D)$ showing the inflammatory cervical lymph node (arrows).

を示唆する頸動脈分岐部周囲組織の濃度上昇と, 血 栓による高度狭窄を認めた(図 2B)。FDG-PET/CT では右頸動脈分岐部周囲に高集積を認め，炎症を示 唆すると考えられた(図 2C, D).

\section{【病理組織学的所見】}

耳鼻科領域の腫瘍，転移性腫瘍，リンパ節腫瘍の 否定および確定診断ため動脈周囲組織と病変部近傍 の頸部リンパ節の生検を行った。

動脈周囲膜組織の病理組織像では，好中球の浸潤 と血管の拡張を伴った線維性組織からなる急性炎症 の像を認めた。腫瘍は除外され, Kikuchi-Fujimoto 病, IgG4 関連動脈周囲炎の可能性も考元免疫組織 染色も行ったが, これも除外された。生検で摘出し た頸部リンパ節もリンパ節の腫大はあったが悪性像 は認めなかった。

\section{【経過 1】}

入院時は抗凝固, 抗炎症治療のために, ヘパリン
とデキサメタゾン 1 日 $8 \mathrm{mg}$ を 5 日間, 退院後は抗 血小板剤としてアスピリンとクロピドグレルを投与 した。ステロイドパルス療法開始後 2 日で頸部痛, 疼痛範囲に改善傾向を認め, 1 週間後に行った MRI でも内頸動脈血管壁肥厚, 血管周囲の腫脹は縮小し た。このような局所炎症所見の改善にかかわらず, 経過観察の超音波検査では, 内頸動脈の血栓による 高度狭窄は大きく改善しなかった。

【ステロイドパルス治療後の頸動脈超音波検査】(図 1)

治療前にみられた内頸動脈血管壁の肥厚，周囲軟 部組織の腫脹が消退していたが，血栓による狭窄の 改善はわずかであった(面積狭窄率 $96.2 \% \rightarrow 86.7 \%$, 狭窄部血流速 $2.99 \mathrm{~m} / \mathrm{s} \rightarrow 2.79 \mathrm{~m} / \mathrm{s}$ ) . 治療前後を比 較してみると, この改善は血栓の縮小より, 内腔側 へ肥厚していた血管壁が退縮したことが大きいこと がわかる。 


\section{【経過 2】}

血栓性狭窄の十分な改善を認めない同部位に頸動 脈ステントを留置した。 現在も再狭窄, 血栓症の再 発は認めず，外来にて経過観察中である.

\section{4. 診断と血栓形成の機序についての考察}

鑑別疾患には，上述のように頸動脈あるいはその 周囲組織に炎症をきたす疾患と腫瘍が挙げられた が，いずれも病理・画像診断所見から除外された。 ことに動脈硬化が単独で血管周囲組織の腫脹の原因 となることない. Wooらは, 頸動脈超音波検査で carotidyniaの治癒する過程を，われわれと同様血管 とその周囲組織の浮腫の軽減で示しだ)。 これらの 経過，所見より，極めてまれであるが，本症例は carotidynia が原因となった内頸動脈の血栓性高度狭 窄と診断した。Carotidynia と頸動脈血栓の間の因果 関係はまだ特定できていない，SLEなど血管炎を呈 する病態において, 血管内皮障害, 凝固傾向の元進 による血栓形成が多く認められる。Carotidynia の病 態からも血管の炎症が関与していることも十分考え られる。一方既存の血管内皮障害, 動脈硬化病变も 関与し, 複合的に血栓形成に作用した可能性があ る。また, Carotidyniaによる血管周囲組織の炎症, 浮腫のため, 頸動脈鞘のなかで血管内腔への圧迫が 加わり，狭窄をきたしたことも関与していると思わ れる。
Carotidynia の診断は一般的でなく³), このような 症例が実は見逃されている可能性がある。今後, carotidynia の病態，ことに血管・血管周囲炎と血栓 形成について解明が進むことを期待したい.

\section{5. おわりに}

以上, 血栓症を合併した carotidynia の稀な症例に ついて概説した。従来, carotidyniaは抗炎症椷が著 効し, 予後良好であるが, 血栓による頸動脈狭窄を 合併する重篤な症例がまれにあり注意を要する。

著者全員の利益相反 (COI)の開示 :

本論文発表内容に関連して開示すべき企業との利益 相反なし

\section{文献}

1) Matsubara H, Takeshita $K$, Nakamura $S$, Murohara T, Miyachi S: Carotidynia with carotid arterial thrombosis. Ann Intern Med 157: 917-919, 2012.

2) Headache Classification Subcommittee of the International Headache Society: The International Classification of Headache Disorders. 2nd edition. Cephalalgia 24 (Suppl 1): 9-160, 2004.

3) Stanbro M, Gray BH, Kellicut DC: Carotidynia: revisiting an unfamiliar entity. Ann Vasc Surg 25: 1144-1153, 2011.

4) Woo JK, Jhamb A, Heran MK, Hurley M, Graeb D: Resolution of existing intimal plaque in a patient with Carotidynia. AJNR Am J Neuroradiol 29: 732-733, 2008. 